Kaveh Rashidi (f. 1988) er medisinsk redaktør

i Tidsskriftet og lege ved Asker og Bærum legevakt.

\title{
Snakk om sex
}

Et godt seksualliv kan ha stor betydning for den enkeltes helse og livskvalitet (1). Sex har for lengst flyttet ut av soverommene og inn i våre felles arenaer, men det er ting som tyder på at legekontorene henger etter. Det finnes imidlertid lite kunnskap om hvor ofte eller i hvilke situasjoner norske leger snakker med sine pasienter om sex.

Sex kan virke som et innlysende tema på legekontoret, for eksempel i forbindelse med klimakterieplager eller prostatakreft. Likevel kan det se ut som om vi unngår å snakke om det selv når indikasjonen er klar. I en studie svarte hver fjerde kvinne som hadde gjennomgått total hysterektomi og nesten halvparten av dem med subtotal hysterektomi at de ikke hadde snakket om sex med helsepersonell i forbindelse med operasjonen (2). Og selv når temaet blir tatt opp, blir det ikke nødvendigvis gjort godt nok: I en kvalitativ studie uttrykker norske kvinner som er blitt operert for underlivskreft et behov for mer informasjon og veiledning om seksuelle endringer (3).

Når vi ikke er gode nok til å snakke om sex ved underlivskreft og hysterektomi, hva når det dreier seg om diagnoser der indikasjonen ikke er like tydelig? Amerikanske og europeiske retningslinjer anbefaler at man snakker med pasientene om sex etter gjennomgått hjerteinfarkt (4). Likevel hadde bare $15 \%$ snakket om sex med legen i etterkant av et hjerteinfarkt, viser en studie fra USA og Spania (5). Oftest var det pasienten selv som hadde tatt opp temaet. Enda mer oppsiktsvekkende er hvilken informasjon pasientene satt igjen med majoriteten fikk råd som ikke var i overensstemmelse med retningslinjene. I en norsk studie har man sett nærmere på holdningene til helsepersonell innen revmatologi (6). Nesten alle (96\%) anså sex som et viktig tema å ta opp med pasientene, likevel gjorde $71 \%$ sjelden eller aldri det. Slike funn gir grunn til bekymring.

God informasjon om sex er ikke bare viktig for pasienter med somatisk sykdom - en tverrsnittsstudie med 16-95-åringer i Danmark viste at $11 \%$ av både menn og kvinner i løpet av det siste året hadde hatt minst ett hyppig gjentagende seksuelt problem (7). Problemforekomsten var høyest hos menn over 60 år og kvinner over 50 år, men også hos kvinner under 30 var den høy. Mange plager, som prematur ejakulasjon og dyspareuni, påvirket mennesker i relativt ung alder. Sex kan altså by på utfordringer i alle aldersgrupper.

Må sex være et problem for at det skal være et tema? Et godt seksualliv har sannsynligvis en forebyggende helseeffekt og kan til og med være assosiert med lavere dødelighet. I en britisk kohortstudie fant man, etter justering for en rekke konfunderende variabler, at totaldødeligheten var redusert med $50 \%$ hos menn som hadde samleie to ganger i uken i forhold til menn som hadde sex sjeldnere enn en gang i måneden (8). Det kan være større forebyggende helsegevinst i et godt sexliv enn i mye annet av det vi bruker tid på å ta opp med pasienten. Så hva skal til for at vi oftere skal snakke om sex?

Det finnes barrierer mot å snakke om sex, men disse kan brytes. Temaet kan være tabubelagt for både lege og pasient. Som med mange tabuer kan det normaliseres gjennom eksponering. Vi må tørre å snakke om sex. Så har vi de praktiske utfordringene: Det kan ta tid å snakke om sex når temaet først kommer på banen. Noen ganger vil det være nødvendig at konsultasjonen skjer på tomannshånd, og for pasienten kan det være av betydning om legen er mann eller kvinne. Vi må altså legge til rette for å snakke om sex. Og det er vanskelig - men viktig - å ha bred kunnskap om forskjellige typer seksuelle problemer (9). Helsepersonell snakker sannsynligvis oftere med pasientene om sex hvis de har utdanning om seksuell helse (6).

Vi skal ikke spørre alle pasientene våre om deres sexliv. Likevel er det et paradoks at vi ikke snakker mer om det på legekontoret når sex synes å være allestedsnærværende i samfunnet for øvrig. Også derfor kan den viktige og fortrolige samtalen om sex utgjøre en stor forskjell. Da må vi leger tørre å ta opp temaet.

\section{Litteratur}

Graugaard C, Pedersen BK, Frisch M. Seksualitet og sundhed. København Vidensråd for Forebyggelse, 2015: 1-43.

2. Lonnée-Hoffmann RA, Schei B, Eriksson NH. Sexual experience of partners after hysterectomy, comparing subtotal with total abdominal hysterectomy. Acta Obstet Gynecol Scand 2006: 85: 1389-94.

3. Sekse RJ, Raaheim M, Blaaka $G$ et al. Cancer as a life-changing process: Women's experiences five years after treatment for gynaecological cancer Int J Qual Stud Health Well-being 2009; 4: 288-98.

4. Steinke EE, Jaarsma T, Barnason SA et al. Sexual counseling for individuals with cardiovascular disease and their partners: a consensus document from the American Heart Association and the ESC Council on Cardiovascular Nursing and Allied Professions (CCNAP). Circulation 2013; 128: 2075-96.

5. Lindau ST, Abramsohn EM, Bueno $\mathrm{H}$ et al. Sexual activity and counseling in the first month after acute myocardial infarction among younger adults in the United States and Spain: a prospective, observational study. Circulation 2014; 130: 2302-9

6. Helland Y, Garratt A, Kjeken I et al. Current practice and barriers to the management of sexual issues in rheumatology: results of a survey of health professionals. Scand J Rheumatol 2013: 42: $20-6$.

7. Christensen BS, Grønbaek M, Osler M et al. Sexual dysfunctions and difficulties in denmark: prevalence and associated sociodemographic factors. Arch Sex Behav 2011; 40: 121-32.

8. Davey Smith G. Frankel S, Yarnell J. Sex and death: are they related? Findings from the Caerphilly Cohort Study. BMJ 1997: 315: 1641-4.

9. Aars H. Menns seksualitet. Oslo: Cappelen Damm, 2011. 